\title{
In vitro Propagation and Callus Formation of Bacopa monnieri (L.) Penn.
}

\author{
Patni Showkat, Yaseer Zaidi, Suhail Asghar and \\ Shamsuddin Jamaluddin
}

\author{
Unijules Life Sciences Ltd., Universal square, Shantinagar, Nagpur-440002, \\ Maharashtra, India
}

Key words: Bacopa monnieri, Micropropagation, Bacoside

\begin{abstract}
An important medicinal herb, namely Bacopa monnieri (L.) Penn. showed best results on MS with $1 \mathrm{mg} / \mathrm{l}$ IAA and $1 \mathrm{mg} / 1 \mathrm{IBA}$ for culture initiation, multiple shoot proliferation, bud breakage, shoot length, shoot numbers and cluster formation. For rooting the best result was obtained on MS solidified with $7 \mathrm{~g} / \mathrm{l}$ of agar along with sugar $20 \mathrm{gm} / 1$ for root, shoot ratio and number of roots. The best hardening was achieved in a mixture of soil : soilrite $(1: 1)$ where the survival rate was $94 \%$. Further, for callus formation the best result was obtained in the leaf explants on MS supplemented with $0.5 \mathrm{mg} / 1$ 2, 4-D. HPLC and HPTLC profile of regenerated shoots revealed a phytochemicals profile similar to that of the market samples and mother plants. The presence of bacoside was detected through HPTLC and HPLC.
\end{abstract}

\section{Introduction}

Medicinal plants are of great interest to the researchers in the field of biotechnology and pharmaceutical as most of the drug industries depend, in part, on plants for the production of pharmaceutical compounds (Chand et al. 1997). Bacopa monnieri (L.) Penn. commonly known as "Brahmi" is an important medicinal herb of the family Scrophulariaceae. It grows on the banks of rivers and lakes. It is the foremost brain tonic herb of the Indian system of medicine and other traditional systems, used primarily as a nerve tonic, to treat insomnia and nervous tension and also imparting a youthful vitality. It also possesses anti-inflammatory, analgesic, antipyretic, epilepsy, anticancer and antioxidant activities (Satyavati et al. 1976). The saponine present in the plant, namely bacoside A, B, C and\& D have been indicating for memory enhancing properties and are called memory chemicals (Chatterjee et al. 1965, Jain et al. 1993, Rastogi et al. 1994). These compounds are attributed with the capability of 
enhancing the transmission efficiency of nerve impulses, thereby strengthening memory and cognition (Singh and Dhawan 1977). The multiple uses and very low drug content of this important medicinal plant have led to ex situ conservation of this endangered medicinal plant.

Micropropagation is rapid, in vitro clonal multiplication method of elite clones help in dissemination and ex situ conservation of endangered medicinal plants. The present communication reports an effective, efficient, rapid, cost effective protocol for large scale in vitro multiplication of Bacopa monnieri.

\section{Materials and Methods}

Healthy plants were obtained from the garden of Unijules Life Sciences Ltd. and the specimen was preserved as herbarium. The healthy, disease free, young nodal explants were selected. Explants were cut and washed under running tap water for $30 \mathrm{~min}$, after that explants were treated with solution containing $0.2 \%$ bavistin and $0.01 \%$ neomycin for $15 \mathrm{~min}$ followed by repeated rinsing with distilled water for $5 \mathrm{~min}$. Further sterilization was done under aseptic conditions inside a laminar air flow hood. Explants were surface sterilized with $70 \%(\mathrm{v} / \mathrm{v})$ ethanol for $1 \mathrm{~min}$ followed by 3 min treatment with $0.01 \%$ (w/v) $\mathrm{HgCl}_{2}$. Finally the explants were washed thoroughly ( 3 - 5 times) with sterilized distilled water. All the glass-ware used is of Borosil.

MS with 3\% sucrose (Himedia), $0.65 \%$ agar (Himedia) and different growth regulators were added in media by micropipette (Tarson). The $\mathrm{pH}$ of all media was adjusted to 5.8 before autoclaving at $121^{\circ} \mathrm{C}(15 \mathrm{~min})$. The chemicals used were of analytical grade (Himedia, Merck and Sigma). Cultures were incubated in a culture room at $25 \pm 2^{\circ} \mathrm{C}$ under $16 \mathrm{hr}$ photoperiod provided by cool white fluorescent tubes (Phillips, India).

Table 1. Different growth regulators combination with MS used for multiple shoot induction.

\begin{tabular}{ll}
\hline Media & Growth regulators combination \\
\hline MS1 & $1.0 \mathrm{mg} / \mathrm{l} \mathrm{IAA}+1.0 \mathrm{mg} / \mathrm{l} \mathrm{IBA}$ \\
MS2 & $0.1 \mathrm{mg} / \mathrm{BA}+0.2 \mathrm{mg} / \mathrm{l} \mathrm{IAA}$ \\
MS3 & $0.2 \mathrm{mg} / \mathrm{BA}+0.1 \mathrm{mg} / \mathrm{l} \mathrm{IAA}$ \\
MS4 & $4.0 \mathrm{mg} / \mathrm{BA}+0.4 \mathrm{mg} / \mathrm{l} \mathrm{NAA}$ \\
MS5 & $0.5 \mathrm{mg} / \mathrm{BA}+0.5 \mathrm{mg} / \mathrm{KIN}$ \\
MS6 & $1.5 \mathrm{mg} / \mathrm{l} \mathrm{BA}$ \\
\hline
\end{tabular}

For shoot initiation and proliferation various explants were inoculated on MS supplemented with different growth regulators (Table 1). The proliferated shoots were transferred into the rooting media for root initiation and elongation (Table 
2). Experiments were performed in replicates of ten and repeated three times. The growth responses of the explants were observed at weekly intervals in terms of the initiation and distribution sites of shoots and root regeneration.

Table 2. Different combinations of MS for root induction.

\begin{tabular}{ll}
\hline Sl. No. & Media combinations \\
\hline RM1 & MS + sucrose $(30 \mathrm{gm} / \mathrm{l})+\operatorname{agar}(6.5 \mathrm{gm} / \mathrm{l})$ \\
RM2 & MS + sucrose $(20 \mathrm{gm} / 1)+\operatorname{agar}(7.0 \mathrm{gm} / \mathrm{l})$ \\
RM3 & MS + sucrose $(20 \mathrm{gm} / 1)+\operatorname{agar}(8.0 \mathrm{gm} / \mathrm{l})$ \\
RM4 & MS + sucrose $(10 \mathrm{gm} / 1)+\operatorname{agar}(7.0 \mathrm{gm} / \mathrm{l})$ \\
RM5 & MS + sucrose $(10 \mathrm{gm} / 1)+\operatorname{agar}(8.0 \mathrm{gm} / 1)$ \\
RM6 & MS + sucrose $(30 \mathrm{gm} / 1)+\operatorname{agar}(7.0 \mathrm{gm} / \mathrm{l})$ \\
\hline
\end{tabular}

Plantlets with developed roots were removed from culture media and after washing roots through running tap water, were transferred to plastic pots containing garden autoclaved soil, farmyard, soil and soilrite different mixtures (Table 3). Better establishment was obtained in soil : soilrite $(2: 1)$ mixture. The plantlets in pots were covered with porous polythene for maintaining high relative humidity (80 - 90\%). Explants, namely leaf segment, scratched leaf segment, intermodal segment and nodal segment were used for callus induction. These explants were inoculated in MS with various combinations of growth regulators (Table 4 ) for better callusing.

Table 3. Different combination for hardening.

\begin{tabular}{lll}
\hline Sl. No. & Soil mixture & Ratio \\
\hline PM1 & Soil : soilrite & $1: 1$ \\
PM2 & Soil : soilrite & $2: 1$ \\
PM3 & Soil & $100 \%$ \\
PM4 & Soil : farmyard & $1: 1$ \\
\hline
\end{tabular}

Table 4. Different growth regulator combination in MS for callusing.

\begin{tabular}{lcl}
\hline Sl. No. & Media & Hormone combination \\
\hline CM1 & MS basal & $0.5 \mathrm{mg} / 1$ 2,4-D and $0.2 \mathrm{mg} / \mathrm{l} \mathrm{Kn}$ \\
CM2 & $"$ & $0.2 \mathrm{mg} / 1$ 2,4-D and $0.1 \mathrm{mg} / \mathrm{l} \mathrm{Kn}$ \\
CM3 & $"$ & $0.5 \mathrm{mg} / 1$ 2,4-D \\
CM4 & $"$ & $0.4 \mathrm{mg} / 12$ 2,-D \\
CM5 & $"$ & $0.3 \mathrm{mg} / 12,4-\mathrm{D}$ \\
CM6 & $"$ & $0.5 \mathrm{mg} / 12$ 2, 4 -D and $0.5 \mathrm{mg} / \mathrm{l} \mathrm{BA}$ \\
\hline
\end{tabular}

Phytochemical evaluation was carried out by HPTLC and HPLC for six months old micropropagated plants, market samples and mother plants. All the 
samples were air dried and made fine powder. Five gm of each sample was refluxed in $50 \mathrm{ml}$ methanol for $2 \mathrm{hr}$ and then filtered with Whatman filter paper No. 2 and evaporated till it reduced to $5 \mathrm{ml}$. The pure marker of bacoside was procured from natural remedies and the solution of $100 \mathrm{ng} / \mu \mathrm{l}$ was prepared in methanol. The separation and determination of bacoside were performed with HPLC columns, the stationary phase was Princetone SPHRE 100 C18 column $(250 \mathrm{~mm} \times 4.6 \mathrm{~mm}, 5 \mu)$ at wavelength $278 \mathrm{~nm}$ at pressure $160 \mathrm{Kgf}$ at flow rate 0.6 $\mathrm{ml} /$ minute mobile phase used was $0.05 \mathrm{M}$ sodium sulphate buffer and acetonitrile (68.5 : $31.5 \mathrm{v} / \mathrm{v})$. For HPTLC, CAMAG (Switzerland) Linomat-V applicator, CAMAG twin trough TLC chamber, a CAMAG TLC scanner-III, CAMAG Wincats software, CAMAG Linomat syringe $(100 \mu \mathrm{l})$ were used. The mobile phase used was ethyl acetate : methanol : water $(6: 1.4: 1)$. The stationary phase used was HPTLC precoated, silica gel 60, F 254 (Merck). The slit dimensions $6 \times 0.30$ micron. The heating time for plate was $5 \mathrm{~min}$ at $110^{\circ} \mathrm{C}$. The plate was derrivatised by spraying with vanillin sulphuric acid.

\section{Results and Discussion}

Earlier reports available for this plant species demonstrated that regenerates on high hormone concentration and its necessity for rooting, however a low hormone concentration and without it for efficient rooting is reported here. The initiation of shoots occurred just within 3 - 4 days and was best obtained on MS supplemented with $1.0 \mathrm{mg} / \mathrm{l} \mathrm{IAA}$ and $1.0 \mathrm{mg} / \mathrm{l} \mathrm{IBA}$. Shoot regeneration potential of IAA has also been reported by Tejavathi and Shailaja (1999). The highest number of shoots (23 - 25) was observed in above media after two weeks. The average length of the shoots was also higher in the above media along with $100 \%$ response and survival rate (Table 5, Fig. 2A, B). Then established shoots were transferred into the rooting media without any hormone and the best result was

Table 5. Response of multiple shooting in different media.

\begin{tabular}{lcccc}
\hline Media & $\begin{array}{c}\text { No. of shoots/ } \\
\text { explant (av.) }\end{array}$ & $\begin{array}{c}\text { Response } \\
(\%)\end{array}$ & $\begin{array}{c}\text { Shoot length } \\
(\mathrm{cm})\end{array}$ & $\begin{array}{c}\text { Field survival } \\
(\%)\end{array}$ \\
\hline MS1 & 18.85 & 100 & 5.3 & 100 \\
MS2 & 04.32 & 70 & 4.8 & 85 \\
MS3 & 10.38 & 84 & 4.6 & 90 \\
MS4 & 06.70 & 78 & 4.0 & 70 \\
MS5 & 08.70 & 85 & 2.9 & 60 \\
MS6 & 03.00 & 70 & 3.2 & 85 \\
\hline
\end{tabular}

achieved in the MS with sucrose $20 \mathrm{gm} / 1$ and agar $7 \mathrm{gm} / \mathrm{l}$. The highest number of roots (8) only after 4 days (Table 6). The plantlets were transferred into the mixture of soil : soilrite with having different combination ratios and the best 


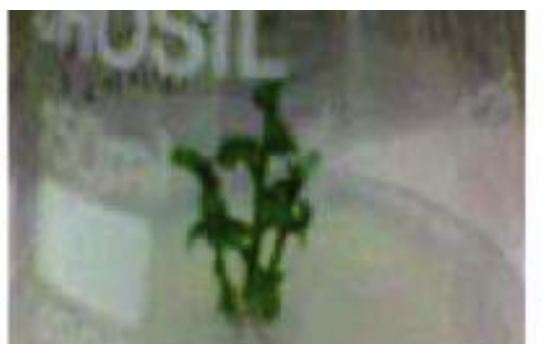

A
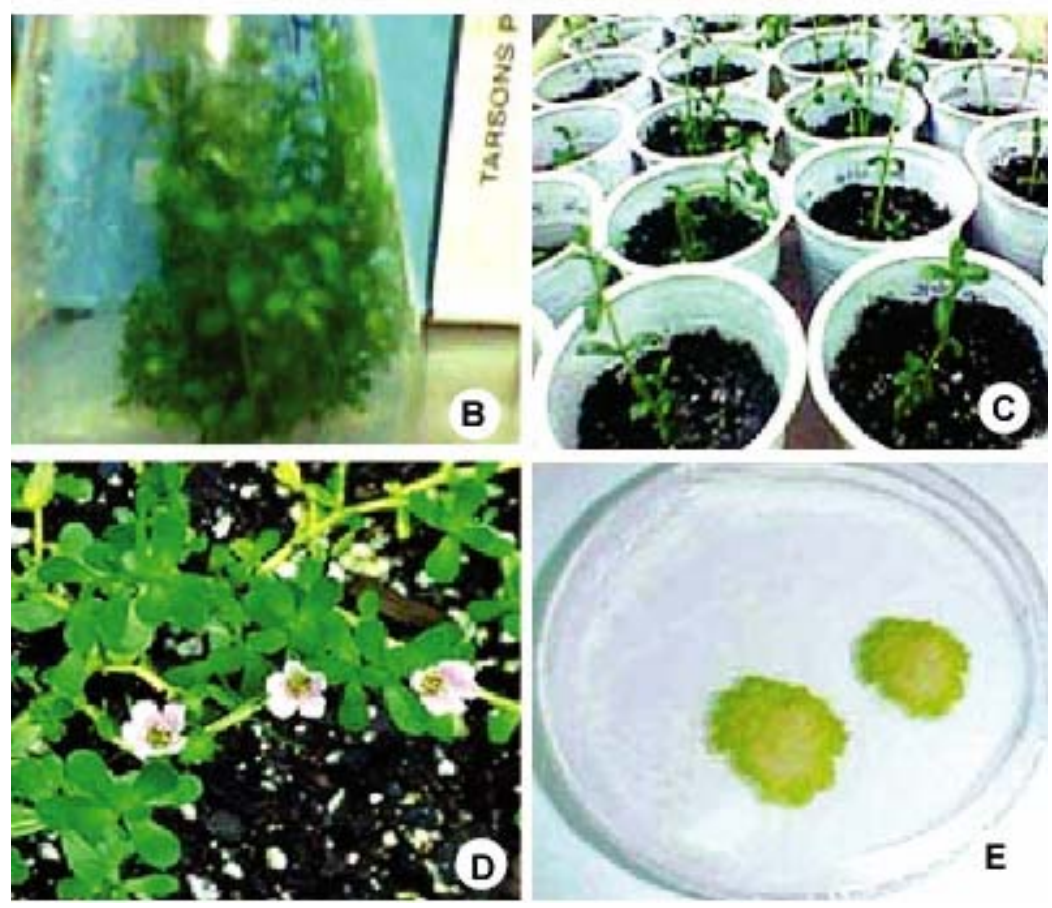

Fig. 1. Photographic representation of micropropagation of Bacopa monnieri. A, B. Multiple shoot. C. Hardening. D. Transfer to field. E. Callus formation.

Table 6. Response of rooting in different media.

\begin{tabular}{lcccc}
\hline Media & $\begin{array}{c}\text { No. of roots/ } \\
\text { explant (av.) }\end{array}$ & $\begin{array}{c}\text { Response } \\
(\%)\end{array}$ & $\begin{array}{c}\text { Shoot length } \\
(\mathrm{cm})\end{array}$ & $\begin{array}{c}\text { Field survival } \\
(\%)\end{array}$ \\
\hline RM1 & 07 & 70 & 4.8 & 90 \\
RM2 & 09 & 100 & 6.9 & 95 \\
RM3 & 06 & 84 & 5.1 & 90 \\
RM4 & 09 & 90 & 4.5 & 70 \\
RM5 & 05 & 90 & 5.0 & 60 \\
RM6 & 05 & 70 & 3.2 & 85 \\
\hline
\end{tabular}


survival was obtained in soil : soilrite $(1: 1)$ when kept in shade for hardening. All plantlets were hardened in nethouse for 20 days and transferred to open field with $100 \%$ survival.

The identification by HPLC and HPTLC revealed the presence of the bacoside and also the fingerprinting profile resembling that of the mother plant and marketed plant which revealed that the raised plants not only resembled the mother plant morphologically but also as chemically (Fig. 1).

Table 7. Response of callusing in different media.

\begin{tabular}{lccc}
\hline Media & $\begin{array}{c}\text { Size of callus } \\
\left(\mathrm{cm}^{2}\right)\end{array}$ & $\begin{array}{c}\text { Callus } \\
\text { establishment }(\%)\end{array}$ & $\begin{array}{c}\text { Callus initiation } \\
\text { (No. of days) }\end{array}$ \\
\hline CM1 & 1.02 & 100 & 7 \\
CM2 & 0.85 & 95 & 6 \\
CM3 & 1.4 & 100 & 4 \\
CM4 & 1.22 & 100 & 5 \\
CM5 & 1.15 & 95 & 6 \\
CM6 & 0.82 & 90 & 5 \\
\hline
\end{tabular}
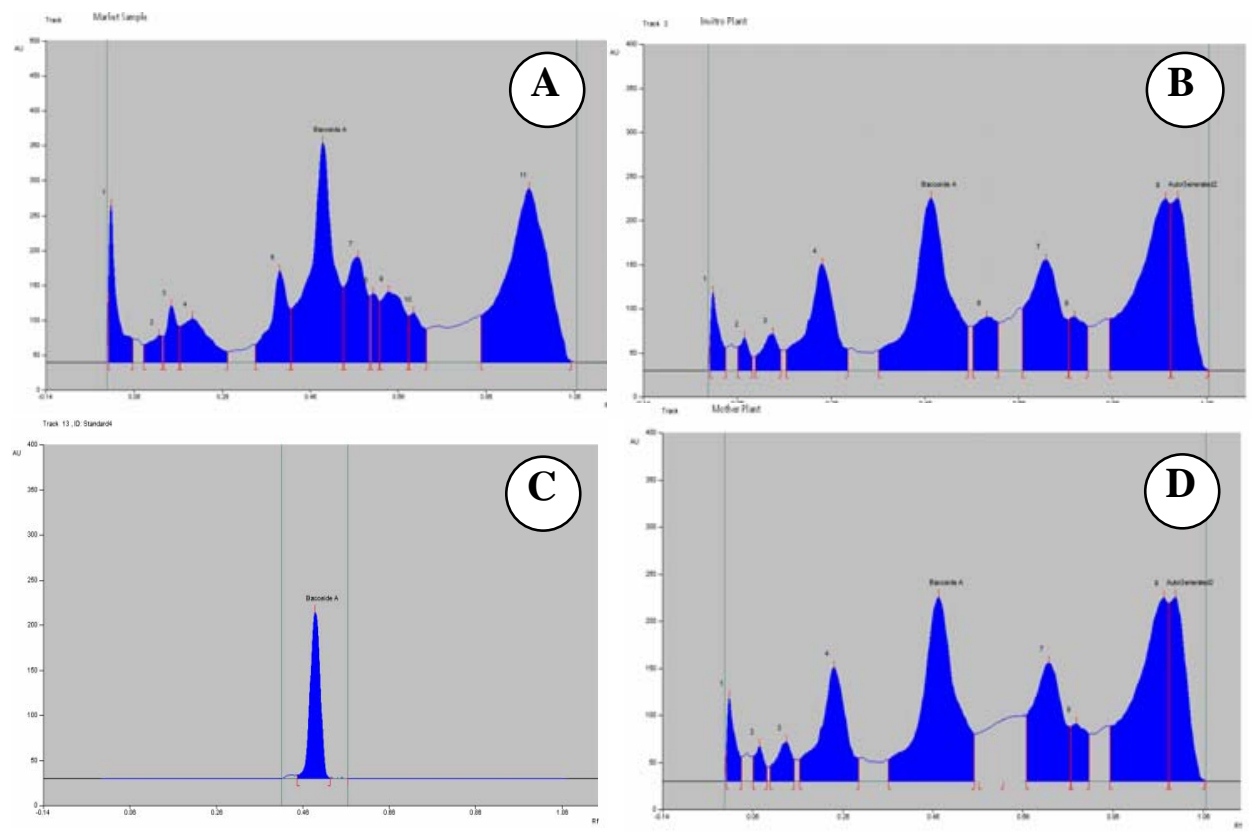

Fig. 1. Comparative presentation of HPTLC densitogram. A. Market plant. B. In vitro plant. C. Bacoside pure marker. D. Mother plant.

It was observed that in the most of the media combinations, callus proliferation was observed on the fourth day of culture. In the entire media 
combinations callus formation was observed but the intensity of callusing was more in $0.5 \mathrm{mg} / \mathrm{l} 2$, 4-D. The callus was yellowish green to brownish and it was soft in nature. Within 12 - 16 days of continuous culture the whole explants was replaced by unorganized callus mass (Table 7, Fig. 1 E).

\section{References}

Chand S, Sahrawat AK and Prakash DVSSR (1997) In vitro culture of Pimpinella anisum L. (anise). J. Plant Biochem. Biotech. 6: 1-5.

Chatterjee N, Rastogi RP Dhar ML (1965) Chemical examination of Bacopa monniera Wettst. Part I: Isolation of chemical constituents. Ind. J. Chem. 3: 24-29.

Jain P and Kulshreshtha DK (1993) Bacoside AI A minor saponins from Bacopa monnieri. Phytochemistry 33: 49-51.

Rastogi S, Mehrotra BN and Kulshreshtha DK (1994) Proceedings of IV international Congress of ethnobiology, Deep publications, New Delhi pp. 93.

Satyavati GV, Raina MK and Sharma M (1976) Indian medicinal plants. Vol. 1 Indian Council of Medical Research, New Delhi, pp. 20-35.

Singh HK, Dhawan BN. (1997) Neuropsycho phamacological effect of the Ayurvedic no tropic Bacopa monnieri Linn. (Brahmi). Ind. J Pharmacol. 29: S359-S365.

Tejavathi DH and Shailaja KS (1999) Regeneration of plants from the cultures of Bacopa monnieri (L.) Pennell. Phytomorphology 49(4): 447-452. 